\title{
Comparison Between Dorsal and Midlateral Approaches in the Treatment of Extra-articular Fractures of Proximal Phalanges with Locked Miniplates
}

\author{
๑ B Birkan Kibar
}

\section{Department of Orthopaedics and Traumatology, Haydarpaşa Numune Training and Research Hospital, İstanbul, Turkey \\ Submitted: 18.09.2019 Accepted: 04.11.2019}

Correspondence: Birkan Kibar Haydarpaşa Numune Eğitim ve Araştırma Hastanesi, Ortopedi ve Travmatoloji Kliniği, İstanbul, Turkey

E-mail: islambol_24@hotmail.com

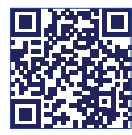

Keywords: Dorsal plating; fracture; internal fixation; lateral plating; phalanx; unstable.

\section{(c) (1) (\$)}

This work is licensed under a Creative Commons Attribution-NonCommercial 4.0 International License.

\begin{abstract}
Objective: We retrospectively examined extra-articular proximal phalangeal fractures excluding the thumb, for which fixation was applied using locked miniplates, with the aim to compare the results of the dorsal and midlateral approaches.
\end{abstract}

Methods: 26 patients were operated via the dorsal approach (Group I) and 20 patients were operated via the midlateral approach (Group 2). No graft was used in any patient. No splint was applied to any patient after the operation. Active finger movements were resumed on postoperative day $\mathrm{I}$.

Results: The mean ages of patients in Groups I and 2 were 35.I (range: 18-60) years and 33.8 (I7-7I) years, respectively. Union was achieved in all patients in the study. In Group I, the mean total active movement (TAM) was $228^{\circ}$ (range: $170-270^{\circ}$ ); according to the digital functional assessment, 18 patients had excellent, 7 patients had good, and I patient had fair results. In Group 2, mean TAM was $239^{\circ}$ (range: $200-270^{\circ}$ ); according to the digital functional assessment, 14 patients had excellent and 6 patients had good results.

Conclusion: We believe that both dorsal and midlateral approaches in extra-articular proximal phalangeal fractures are effective and reliable methods with similar clinical and functional results, and are thus a suitable alternative for each other.

\section{INTRODUCTION}

The phalanx is the most common site for fractures of the hand and accounts for approximately $10 \%$ of all hand injuries. ${ }^{[l]}$ The interosseous muscles insert at or near the proximal phalanx and force proximal fracture fragment flexion, causing dorsal angulation. The flexor and extensor tendons shorten the phalanx by applying longitudinal compression force and force the distal fragment into extension. ${ }^{[2]}$ Most proximal phalangeal fractures are stable and can be treated with a cast or splint, and surgical treatment is required for unstable fractures. ${ }^{[3]}$ Surgical treatment options include closed or open reduction and percutaneous pinning, extra or intraosseous wiring, lag screws, intramedullary devices, plates and external fixators. ${ }^{[3-7]}$ Plate fixation helps achieve stable fixation, facilitating early postoperative movement. ${ }^{[8]}$ Complications such as stiffness, flexion contracture in the proximal interphalangeal (PIP) joint, extension loss and symptomatic hardware are common after plate fixation. ${ }^{[9]}$
Dorsal and midlateral approaches are used in the surgical treatment of proximal phalangeal fractures. In the dorsal approach, the extensor tendon is split longitudinally; this approach has the disadvantage of causing scarring of the dorsal aponeurosis to bone and skin. The advantages of the midlateral approach are that the extensor tendon is not iatrogenically injured and the plate does not participate in tendon adhesion. ${ }^{[10]}$

In our study, we retrospectively examined extra-articular proximal phalangeal fractures excluding the thumb, for which fixation was applied using locked miniplates, with the aim to compare the results of the dorsal and midlateral approaches.

\section{MATERIALS AND METHODS}

We retrospectively evaluated adult patients with extra-articular proximal phalangeal fractures excluding the 
thumb treated with locked miniplates between 2014 and 2018. Patients for whom at least one-year follow-up data were available, were called by telephone and those who responded to the last control call were included in the study. Ethics committee approval for the study (2018-650) and written informed consent were obtained from all patients. Patients with open fractures, pathological fractures, fracture extending to joints, incomplete bone maturation, additional injuries in the same extremity and surgery wait time more than 7 days and those who had undergone a surgery for the same extremity before were excluded from the study. Twelve patients could not be reached, in all, 46 fingers of 46 patients who met the inclusion criteria were included in the study.

Fractures were classified as transverse, spiral-oblique or comminuted depending on the fracture pattern. In cases where reduction could not be achieved by closed methods, the presence of malalignment or rotational deformity was considered as an indication for internal fixation. Preoperative surgical approach selection was made according to the personal preference of different surgeons. In our clinic some surgeons prefer to use only dorsal approach, others prefer to use only midlateral approach for proximal phalanx fractures. Patients were operated under general or axillary block anaesthesia.

\section{Surgical technique}

In Group I, a longitudinal incision was made from the dorsal side of the proximal phalanx. The extensor tendon was split longitudinally at the midline. After clearing the blood clots and soft tissue in the fracture line, reduction performed and a locked miniplate was applied from the dorsal side of the proximal phalanx. At least three locking screws (six cortices) were applied on both sides of the fracture line. Fluoroscopic control was performed and the extensor tendon was repaired with non-absorbable sutures (Fig. I). In Group 2, a midlateral incision was made from the radial or ulnar side of the proximal phalanx. The lateral band was incised. After clearing the blood clots and soft tissue in the fracture line, reduction was performed and a locked miniplate was applied from the lateral side of the proximal phalanx. At least three locking screws (six cortices) were applied on both sides of the fracture line (Fig. 2).

No graft was used in any patient. Extra lag screws were used in five patients, and $1.5-\mathrm{mm}$ fixed angle locked miniplates were used for all patients. No splint was applied to any patient after the operation. Active finger movements of the distal interphalangeal (DIP), PIP, and metacarpophalangeal (MP) joints were resumed on postoperative day I. Ice packs were used for the first week for oedema control. Daily activities such as eating, pen holding and dressing were allowed for the first three weeks. After three weeks, the patients consulted the physical medicine and rehabilitation unit, and a hand rehabilitation program was initiated for I h/day and 5 days/week, including neuromuscular electric stimulation and stretching exercises. Strengthening exercises were initiated at postoperative week 6 .
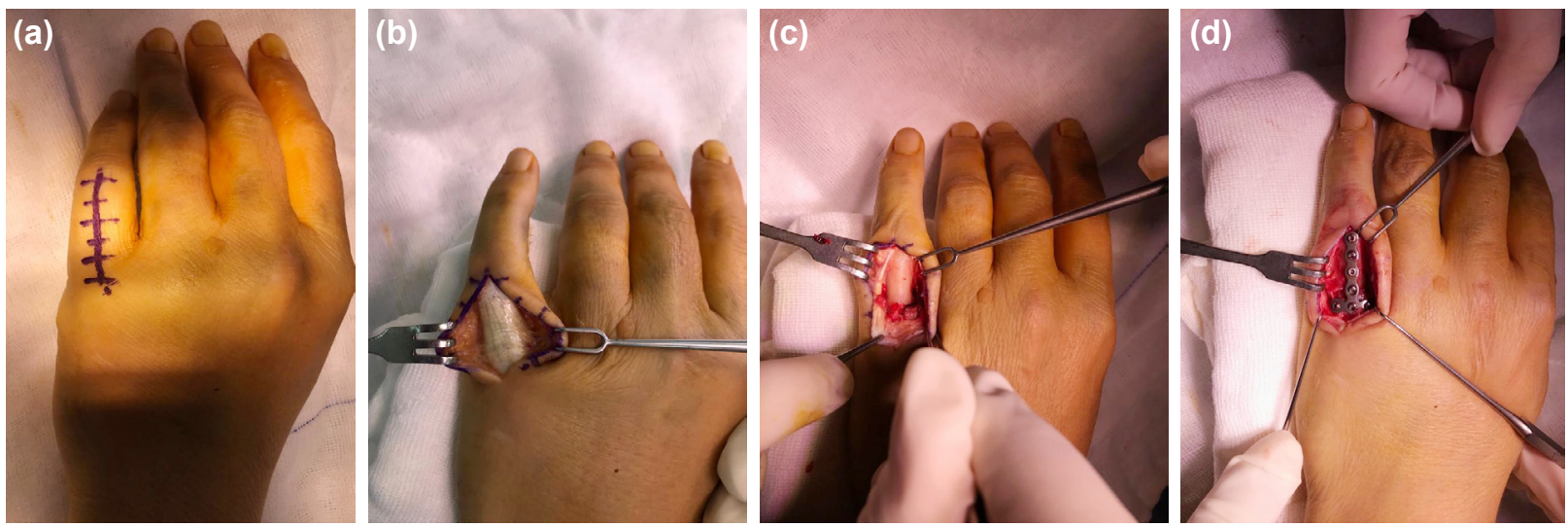

Figure 1. (a-d) Dorsal plate placement with dorsal incision, extensor mechanism is split longitudinally to gain fracture visualization.
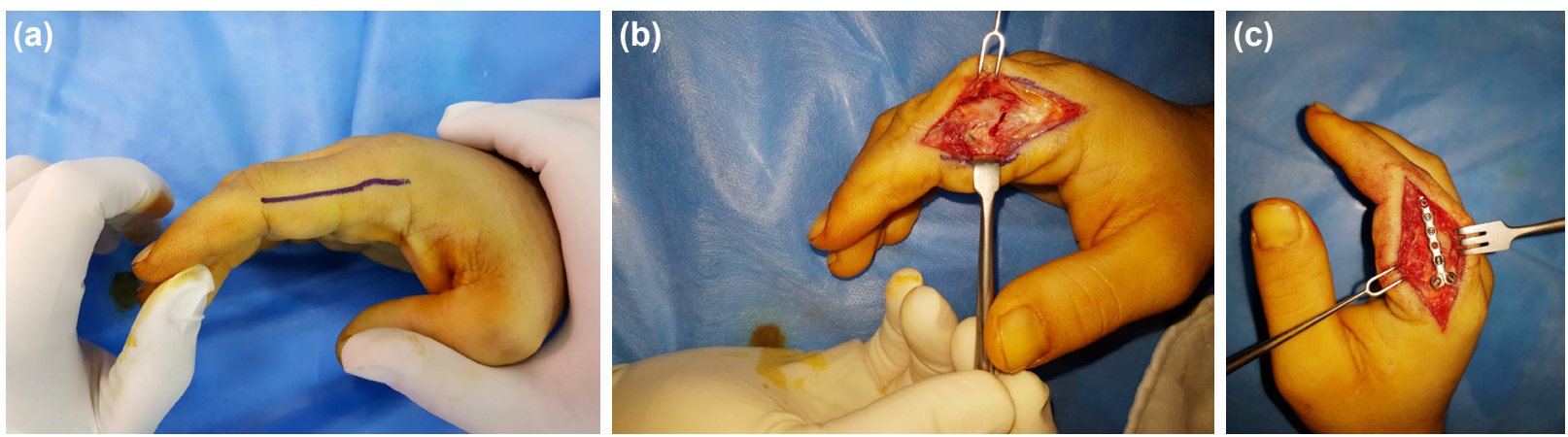

Figure 2. (a-c) Lateral plate placement with midlateral incision, extensor mechanism is retracted to gain fracture visualization. 
Recent examinations were performed by a physical therapy and rehabilitation specialist in our hospital, experienced in hand therapy, independent of the surgical team. In the last follow-up, the DIP, PIP and MP joint range of motion were measured using a finger goniometer. Total active range of motion (TAM) was calculated by subtracting the sum of DIP, PIP and MP joint extensor lag from MP, PIP and DIP joint flexion for the affected finger, and digital functional assessment was evaluated based on the TAM scores (Table I). ${ }^{[1]}$ Using posteroanterior, oblique and lateral radiographs, union was defined as cortical trabeculation and formation of a bridging callus and no sensitivity upon palpation on the fracture line. The absence of a bridging callus after six months was evaluated as non-union. ${ }^{[12]}$ In addition, the Disabilities of the Arm, Shoulder, and Hand (DASH) questionnaire, and the visual analogue scale (VAS) were used for functional and pain evaluation. ${ }^{[13,14]}$

\section{Statistical analysis}

A priory power analysis was performed to detect significant differences $(p<0.05)$ between groups using Student's t-test with an effect size of 0.6. The Pearson's chi-square test, Fisher's exact test, Fisher-Freeman-Halton exact tests were used to compare qualitative data. $\mathrm{P}<0.05$ was considered statistically significant.

\section{RESULTS}

In this study, 26 patients were operated via the dorsal approach (Group I) and 20 patients were operated via the midlateral approach (Group 2). The mean follow- up time was 23.I (range: 12-34) and 24.9 (range: 12-36) months for Groups I and 2, respectively. There were 19 men and 7 women and 12 men and 8 women in Groups $I$ and 2, respectively. The mean ages of patients in Groups I and 2 were 35.1 (range: 18-60) years and 33.8 (I7-7I) years, respectively. A detailed analysis of the demographic data is shown in Table 2.

In Group I, the mean PIP joint extension loss was $3.6^{\circ}$ (observed in 9 patients, range: $5-25^{\circ}$ ), mean PIP joint flexion was $90.1^{\circ}\left(60-100^{\circ}\right)$, mean MP joint extension loss was $1.3^{\circ}$ (observed in 3 patients, range $10-15^{\circ}$ ), and mean $\mathrm{MP}$ joint flexion was $86.9^{\circ}\left(80-90^{\circ}\right)$. The mean DASH score was 5.2 (range: $0-16.7$ ), and the mean VAS score was I.I (range: 0-3). In Group 2, mean PIP joint extension loss was $3.2^{\circ}$ (observed in 6 patients, range: $5-20^{\circ}$ ), mean PIP joint flexion was $93.5^{\circ}\left(70-100^{\circ}\right)$, mean MP joint extension loss was $1^{\circ}$ (observed in 2 patients, $10-10^{\circ}$ ), mean

Table I. Digital functional assessment

\begin{tabular}{lc}
\hline Result & Total active range of motion \\
\hline Excellent & $220^{\circ}-260^{\circ}$ \\
Good & $180^{\circ}-219^{\circ}$ \\
Fair & $130^{\circ}-179^{\circ}$ \\
Poor & $<130^{\circ}$ \\
\hline
\end{tabular}

MP joint flexion was $87^{\circ}\left(80-90^{\circ}\right)$, mean DASH score was 4.2 (0-13.3) and mean VAS score was I.2 (range: 0-2). Complete range of motion for DIP and wrist joints was achieved in all patients. In Group I, the mean TAM was $228^{\circ}$ (range: $170-270^{\circ}$ ); according to the digital functional assessment, 18 patients had excellent, 7 patients had good, and I patient had fair results. In Group 2, mean TAM was $239^{\circ}$ (range: $200-270^{\circ}$ ); according to the digital functional assessment, 14 patients had excellent and 6 patients had good results. No statistically significant difference was found between groups in terms of age, gender, affected side, affected finger, trauma mechanism, smoking status, fracture pattern, surgery wait time, follow-up time, surgery time, DASH scores, VAS scores, PIP joint extension lag, PIP joint flexion degree, MP joint extension lag, MP joint flexion degree and TAM ( $p>0.05)$. A detailed analysis of parameters between groups is shown in Table 3.

Union was achieved in all patients in the study. No patient experienced implant irritation, implant prominence, implant migration, hardware loosening, reduction loss and/or malunion, and no implant was removed from any patient. Also, no patient had infection, digital nerve injury, hypertrophic scarring and/or rotational deformity. No tenolysis was performed for finger stiffness, and no secondary sur-

Table 2. Summary of demographic information of patients

\begin{tabular}{|c|c|c|c|}
\hline & $\begin{array}{c}\text { Group I } \\
\text { dorsal } \\
\text { incision } \\
(n=26)\end{array}$ & $\begin{array}{c}\text { Group } 2 \\
\text { midlateral } \\
\text { incision } \\
(n=20)\end{array}$ & $\mathbf{p}$ \\
\hline Mean age (range) & $35.1(18-60)$ & $33.8(|7-7|)$ & 0.764 \\
\hline Gender & & & 0.348 \\
\hline Male & 19 & 12 & \\
\hline Female & 7 & 8 & \\
\hline Side & & & 0.938 \\
\hline Right & 14 & 11 & \\
\hline Left & 12 & 9 & \\
\hline Trauma mechanism & & & 0.847 \\
\hline Fall & 13 & II & \\
\hline Traffic accident & I & I & \\
\hline Sports injury & 3 & 2 & \\
\hline Work accident & 6 & 4 & \\
\hline Punch & 3 & I & \\
\hline Assault & 0 & I & \\
\hline Affected finger & & & 0.945 \\
\hline index & 9 & 8 & \\
\hline middle & 3 & 3 & \\
\hline ring & 6 & 4 & \\
\hline little & 8 & 5 & \\
\hline Fracture pattern & & & 0.790 \\
\hline transverse & 7 & 4 & \\
\hline spiral- oblique & 12 & 9 & \\
\hline comminuted & 7 & 7 & \\
\hline Dominant side & 14 & II & 0.938 \\
\hline Smoking status & 12 & 10 & 0.796 \\
\hline
\end{tabular}


Table 3. Summary of medical information of patients

\begin{tabular}{|c|c|c|c|}
\hline & Group I dorsal incision & Group 2 midlateral incision & $\mathbf{p}$ \\
\hline & $(n=26)$ & $(n=20)$ & \\
\hline Mean follow-up time (month, range) & $23.1(12-34)$ & $24.9(12-36)$ & 0.484 \\
\hline Mean time between injury and surgery (day, range) & $4.3(I-7)$ & $4.5(1-7)$ & 0.262 \\
\hline Mean operation time (minute) (range) & $41.9(30-75)$ & $40.2(30-70)$ & 0.553 \\
\hline Anesthesia type & & & 0.855 \\
\hline General & II & 9 & \\
\hline Axillary block & 15 & 11 & \\
\hline Mean TAM (degree) & 228 & 239 & 0.140 \\
\hline Excellent & 18 & 14 & \\
\hline Good & 7 & 6 & \\
\hline Fair & 1 & 0 & \\
\hline Mean hospitalization time (day) & 2.7 & 2.8 & 0.694 \\
\hline Mean PIP joint extension lag (degree) & 3.6 & 3.2 & 0.810 \\
\hline Mean PIP joint flexion (degree) & 90.1 & 93.5 & 0.681 \\
\hline Mean MP joint extension lag (degree) & 1.3 & 1 & 0.837 \\
\hline Mean MP joint flexion (degree) & 86.9 & 87 & 0.897 \\
\hline Mean VAS score & I.I & 1.2 & 0.817 \\
\hline Lag screw usage & 2 & 3 & 0.430 \\
\hline Mean DASH score & 5.2 & 4.2 & 0.433 \\
\hline
\end{tabular}

TAM: Total active movement; PIP: Proximal interphalangeal; MP: Metacarpophalangeal; VAS: Visual analogue scale; DASH: Disabilities of the Arm, Shoulder, and Hand.

gery was required in any patient. In all, 2 and I patients in Groups I and 2 had transient reflex regional pain syn- drome; this was improved by conservative treatment in all patients (Figs. 3, 4).
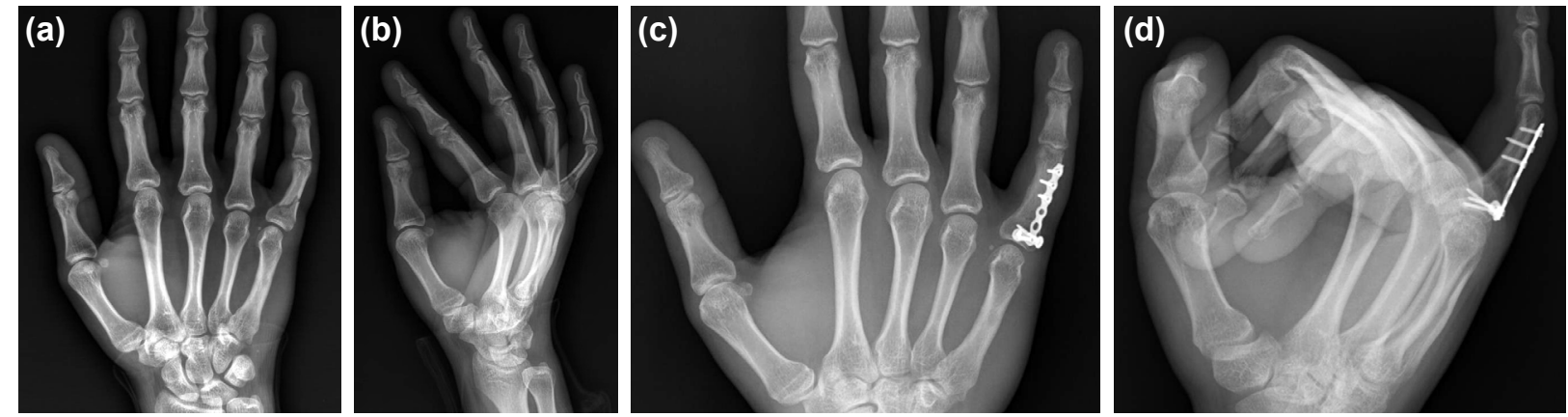

Figure 3. 23 year-old male, fracture of the right little finger proximal phalanx, (spiral- oblique type), (a, b) Preoperative posterioranterior and lateral radiographs, (c, d) 3-month postoperative posterior-anterior and lateral radiographs.
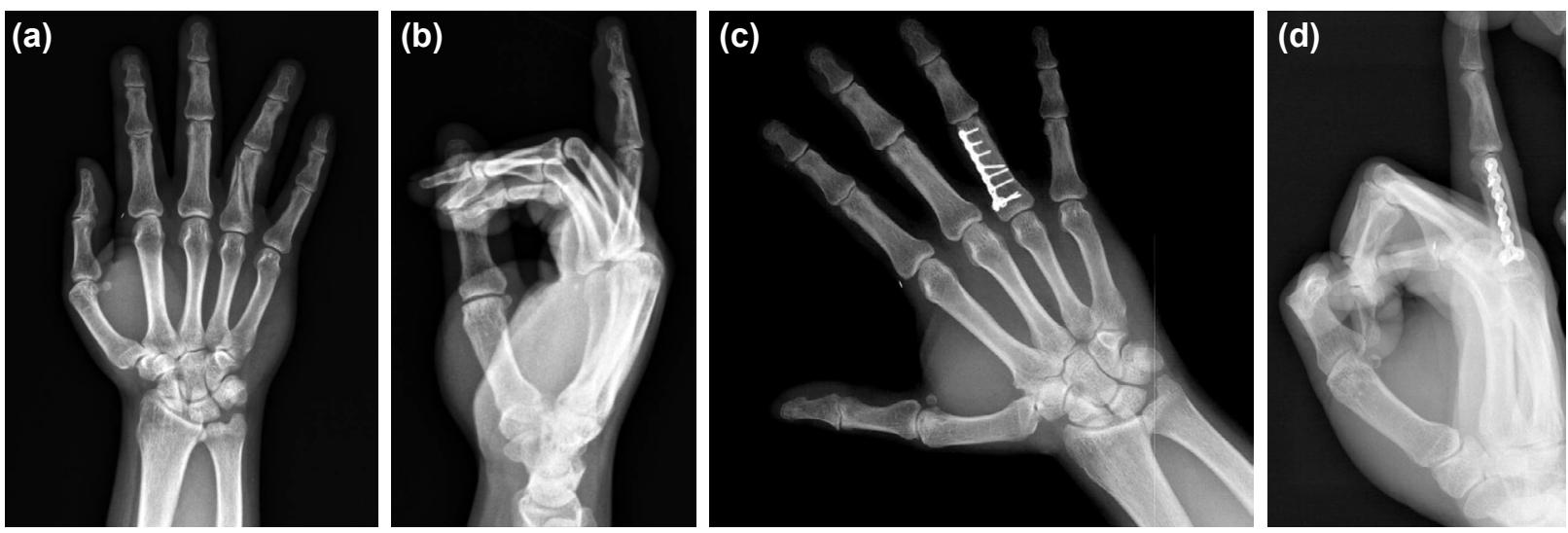

Figure 4. 48 year-old male, fracture of the right ring finger proximal phalanx, (comminuted type), (a, b) Preoperative posterior-anterior and lateral radiographs, (c, d) 3-month postoperative posterior-anterior and lateral radiographs. 


\section{DISCUSSION}

The purpose of treatment for proximal phalangeal fractures is to provide fracture healing with acceptable alignment and to maintain flexor and extensor tendon functions. Plate fixation in hand fractures is more rigid compared with other fixation methods and has gained popularity in recent years. ${ }^{[15]}$ Proximal phalanx is better visualized by dorsal approach; further, the dorsal surface is flat and the plate is better adapted. However, as the extensor tendon is splitted longitudinally, extension loss can be seen and adhesion can develop because of mechanical friction between the tendon and the implant or because of foreign body reaction. The extensor tendon is not injured iatrogenically by the application of plate to the lateral side of the proximal phalanx via the midlateral approach, and is retracted to better view the fracture. Technically, it is more difficult to adapt the plate to the bone, to see the fracture and to provide reduction via this approach. In a cadaveric biomechanical study comparing dorsal and lateral plates, the importance of the lateral placement of the plate was emphasized as being less invasive and causing less soft tissue damage; it was concluded that dorsal and lateral plate placements had similar efficacy in proximal phalangeal fractures. ${ }^{[16]}$ In another biomechanical cadaver study comparing dorsal and lateral plates, it was shown that $1.5-\mathrm{mm}$ non-locking dorsal plate placement did not have a biomechanical advantage over lateral locking plate placement in proximal phalangeal fractures and that $1.3-\mathrm{mm}$ low-profile lateral locking plates provided more rigid fixation. ${ }^{[17]}$ Robinson et al..$^{[9]}$ treated twenty-five extra-articular proximal phalangeal fractures with dorsal plating and 17 fractures with lateral plating, and they found no difference in terms of results between both approaches. Omokawa et al. ${ }^{[18]}$ achieved better results with lateral plating than with dorsal plating in proximal phalangeal fractures treated with low-profile locking plates in terms of TAM, and suggested the use of lateral plate placement unless there was comminution and intra-articular fragmentation. Onishi et al. ${ }^{[19]}$ emphasized that comminution and dorsal plate placement are risk factors for joint stiffness, and suggested screw fixation by midlateral approach in unstable proximal phalangeal fractures. In our study, we applied dorsal plating with dorsal approach in 26 extra-articular proximal phalangeal fractures and lateral plating with midlateral approach in 20, and obtained union in all fractures with similar functional results between groups.

In our study, open fractures and fractures extending to joints were not included as they would affect the results. In addition, both groups had similar distribution according to the fracture pattern. TAM, digital functional assessment and DASH and VAS scores were evaluated for functional results. When the literature was reviewed, Dabezies et al. ${ }^{[20]}$ applied miniplates to 22 proximal phalangeal fractures via the midlateral approach and obtained mean TAM of $243^{\circ}$. Pun et al. ${ }^{[2]]}$ applied dorsal plates or lag screws with dorsal or dorsolateral approach to 36 proximal phalangeal fractures, and obtained good, fair and poor results in 10,
13 and 13 patients, respectively. Page et al. ${ }^{[10]}$ applied dorsal plate to 37 phalangeal fractures and obtained excellent, good, fair and poor results in 3, I, 10 and 23 patients. Brei-Thoma et al. ${ }^{[22]}$ applied low-profile, locked dorsal plates to 36 extra-articular phalangeal fractures, found an average TAM of $213^{\circ}$; further, they obtained excellent, good, moderate and poor results in 9, 9, 3 and 8 patients, respectively, and extension lag developed in $67 \%$ of fingers. The most appropriate study in terms of comparison with our study is the work of Robinson et al. ${ }^{[9]}$ They treated 25 patients with extra-articular proximal phalangeal fractures with dorsal and 17 patients with lateral plate; the mean TAM reported in their study was $186^{\circ}$ in the dorsal group, and $185^{\circ}$ in the lateral group. Finger stiffness is the most common complication of phalangeal fractures. In our study, the most common complication was extension lag, too. In Group I, loss of PIP joint extension was observed in 9 patients $\left(5-25^{\circ}\right)$ and loss of MP joint extension was observed in 3 patients (10-15 ); in Group 2, PIP joint extension loss was observed in 6 patients $\left(5-20^{\circ}\right)$ and MP joint extension loss was observed in 2 patients $\left(10^{\circ}\right)$. The degree of loss observed in our study accordingly seems to be compatible with that reported in the literature. There was no need for secondary surgery and tenolysis. We believe that rehabilitation should be started early to prevent joint stiffness. In our study, we did not use a splint in any of the patients and immediately started active movement. We ensured patient consultation to the physical medicine and rehabilitation department, the patients underwent a hand rehabilitation program and they were followed up weekly at the outpatient clinic. We believe that splint application is unnecessary for oedema and pain control after miniplate application in proximal phalangeal fractures. We did not apply a splint after the surgery, and none of the patients had oedema and/or excessive pain. In addition, we believe that starting finger movement on first day after surgery reduces the formation of adhesions. Further, we believe that if both sides of the fracture are fixed with at least three locking screws (six cortices), sufficient stability is provided and early movement can be initiated. Because of early motion, no reduction and alignment loss and no implant failure were observed in any patient in this study. Union was achieved in all fractures; no implant irritation was observed and no implant removal was performed. After obtaining similar TAM and digital functional assessment results in both groups, we concluded that the application of the plate from the dorsal and lateral side had similar effects on finger stiffness. Because of the production of low-profile plates with locking screw technology, it is possible to obtain better results by applying the plate from the dorsal side beneath the extensor tendon.

The retrospective design of the study and the selection of surgical technique based on the surgeon's personal preference were the limitations of the study. In our personal experience, it was easier to visualize the fracture, reduce it, and adapt the plate with the dorsal approach. Particularly, we had difficulty in reducing the fracture with the midlateral approach in comminuted fractures. We also needed 
to bend the plate most of the times in order to adapt the plate with the midlateral approach.

Finally, we believe that both dorsal and midlateral approaches in extra-articular proximal phalangeal fractures are effective and reliable methods with similar clinical and functional results, and are thus a suitable alternative for each other.

\section{Funding}

The authors declare that this research received no specific grant from any funding agency in the public, commercial, or not-for-profit sectors.

Ethics Committee Approval

Approved by the local ethics committee (2018-650).

Informed Consent

Retrospective study.

Peer-review

Internally peer-reviewed.

Authorship Contributions

Concept: B.K.; Design: B.K.; Supervision: B.K.; Fundings: B.K.; Materials: B.K.; Data: B.K.; Analysis: B.K.; Literature search: B.K.; Writing: B.K.; Critical revision: B.K.

\section{Conflict of Interest}

None declared.

\section{REFERENCES}

1. Jehan S, Chandraprakasam T, Thambiraj S. Management of proximal phalangeal fractures of the hand using finger nail traction and a digital splint: a prospective study of 43 cases. Clin Orthop Surg 2012;4:156-62. [CrossRef]

2. Lögters TT, Lee HH, Gehrmann S, Windolf J, Kaufmann RA. Proximal Phalanx Fracture Management. Hand (N Y) 2018;13:376-83.

3. Ouellette EA, Freeland AE. Use of the minicondylar plate in metacarpal and phalangeal fractures. Clin Orthop Relat Res 1996;327:38-46.

4. Kozin SH, Thoder JJ, Lieberman G. Operative treatment of metacarpal and phalangeal shaft fractures. J Am Acad Orthop Surg 2000;8:111-21. [CrossRef]

5. Saied AR, Sabet Jahromi M. Treatment of proximal phalanx fractures: transarticular pinning the metacarpophalangeal joint or cross pinning from the base of the proximal phalanx-a prospective study. Eur J Trauma Emerg Surg 2019;45:737-43. [CrossRef]

6. Shim WC, Yang JW, Roh SY, Lee DC, Kim JS. Percutaneous cerclage wiring technique for phalangeal fractures. Tech Hand Up Extrem Surg 2014;18:36-40. [CrossRef]

7. Margić K. External fixation of closed metacarpal and phalangeal fractures of digits. A prospective study of one hundred consecutive patients. J Hand Surg Br 2006;31:30-40. [CrossRef]

8. Kodama N, Takemura Y, Ueba H, Imai S, Matsusue Y. Operative treatment of metacarpal and phalangeal fractures in athletes: early return to play. J Orthop Sci 2014;19:729-36. [CrossRef]

9. Robinson LP, Gaspar MP, Strohl AB, Teplitsky SL, Gandhi SD, Kane PM, et al. Dorsal versus lateral plate fixation of finger proximal phalangeal fractures: a retrospective study. Arch Orthop Trauma Surg 2017;137:567-72. [CrossRef]

10. Page SM, Stern PJ. Complications and range of motion following plate fixation of metacarpal and phalangeal fractures. J Hand Surg Am 1998;23:827-32. [CrossRef]

11. Duncan RW, Freeland AE, Jabaley ME, Meydrech EF. Open hand fractures: an analysis of the recovery of active motion and of complications. J Hand Surg Am 1993;18:387-94. [CrossRef]

12. Kurzen P, Fusetti C, Bonaccio M, Nagy L. Complications after plate fixation of phalangeal fractures. J Trauma 2006;60:841-3. [CrossRef]

13. Hudak PL, Amadio PC, Bombardier C. Development of an upper extremity outcome measure: the DASH (disabilities of the arm, shoulder and hand) [corrected]. The Upper Extremity Collaborative Group (UECG). Am J Ind Med 1996;29:602-8. [CrossRef]

14. Cooney WP, Bussey R, Dobyns JH, Linscheid RL. Difficult wrist fractures. Perilunate fracture-dislocations of the wrist. Clin Orthop Relat Res 1987;214:136-47. [CrossRef]

15. Başar H, Başar B, Başçı O, Topkar OM, Erol B, Tetik C. Comparison of treatment of oblique and spiral metacarpal and phalangeal fractures with mini plate plus screw or screw only. Arch Orthop Trauma Sur. 2015;135:499-504. [CrossRef]

16. Ouellette EA, Dennis JJ, Latta LL, Milne EL, Makowski AL. The role of soft tissues in plate fixation of proximal phalanx fractures. Clin Orthop Relat Res 2004;418:213-8. [CrossRef]

17. Shanmugam R, Ernst M, Stoffel K, Fischer MF, Wahl D, Richards $\mathrm{RG}$, et al. Angular stable lateral plating is a valid alternative to conventional plate fixation in the proximal phalanx. A biomechanical study. Clin Biomech (Bristol, Avon) 2015;30:405-10. [CrossRef]

18. Omokawa S, Fujitani R, Dohi Y, Okawa T, Yajima H. Prospective outcomes of comminuted periarticular metacarpal and phalangeal fractures treated using a titanium plate system. J Hand Surg Am 2008;33:857-63. [CrossRef]

19. Onishi T, Omokawa S, Shimizu T, Fujitani R, Shigematsu K, Tanaka Y. Predictors of Postoperative Finger Stiffness in Unstable Proximal Phalangeal Fractures. Plast Reconstr Surg Glob Open 2015;3:e431.

20. Dabezies EJ, Schutte JP. Fixation of metacarpal and phalangeal fractures with miniature plates and screws. J Hand Surg Am 1986;11:283-8. [CrossRef]

21. Pun WK, Chow SP, So YC, Luk KD, Ngai WK, Ip FK, et al. Unstable phalangeal fractures: treatment by A.O. screw and plate fixation.J Hand Surg Am 1991;16:113-7. [CrossRef]

22. Brei-Thoma P, Vögelin E, Franz T. Plate fixation of extra-articular fractures of the proximal phalanx: do new implants cause less problems? Arch Orthop Trauma Surg 2015;135:439-45. [CrossRef] 
Kilitli Mini Plaklar ile Proksimal Falanksların Ekstraartiküler Kırıklarının Tedavisinde Dorsal ve Midlateral Yaklaşımların Karşılaştırılması

Amaç: Kilitli mini plaklar kullanılarak fiksasyon uygulanan başparmak dışındaki eklem dışı proksimal falanks kırıklarında, dorsal ve midlateral yaklaşımların sonuçlarını geriye dönük olarak inceleyip karşılaşırımayı amaçladık.

Gereç ve Yöntem: Yirmi altı hasta dorsal yaklaşımla (Grup I) ve 20 hasta midlateral yaklaşımla ameliyat edildi (Grup 2). Hiçbir hastada greft kullanılmadı. Ameliyat sonrası hiçbir hastaya atel uygulanmadı. Ameliyat sonrası birinci günde aktif parmak hareketlerine başlandı.

Bulgular: Grup I ve grup 2'deki hastaların yaş ortalamaları sırasıyla 35.I (18-60) ve 33.8 (I7-7I) idi. Çalışmadaki tüm hastalarda kaynama sağlandı. Grup I'de ortalama toplam aktif hareket (TAM) $228^{\circ}\left(170-270^{\circ}\right)$; dijital fonksiyonel değerlendirmeye göre, 18 hasta mükemmel, yedi hasta iyi, bir hasta iyi sonuç ald. Grup 2'de ortalama TAM $239^{\circ}\left(200-270^{\circ}\right)$; dijital fonksiyonel değerlendirmeye göre 14 hasta mükemmel, altı hasta iyi sonuç aldı.

Sonuç: Eklem dışı proksimal falanks kırıklarında, dorsal ve midlateral yaklaşımların benzer klinik ve fonksiyonel sonuçlarla etkili ve güvenilir yöntemler olduğuna ve bu nedenle birbirleri için uygun bir alternatif olduğuna inanıyoruz.

Anahtar Sözcükler: Dengesiz; dorsal plaklama; falanks; iç tespt; kırık; lateral plaklama. 